\title{
Rhodobacter veldkampii, a New Species of Phototrophic Purple Nonsulfur Bacteria
}

\author{
T. A. HANSEN ${ }^{1}$ AND J. F. IMHOFF ${ }^{2 *}$ \\ Laboratory of Microbiology, University of Groningen, Haren, The Netherlands, ${ }^{1}$ and Institut für Mikrobiologie, \\ Rheinische Friedrich-Wilhelms-Universität, D-5300 Bonn, Federal Republic of Germany ${ }^{2}$
}

\begin{abstract}
We describe a new species of purple nonsulfur bacteria, which has the ability to grow under photoautotrophic growth conditions with sulfide as an electron donor and shows the characteristic properties of Rhodobacter species (i.e., ovoid to rod-shaped cells, vesicular internal photosynthetic membranes, bacteriochlorophyll $a$ and carotenoids of the spheroidene series as photosynthetic pigments). In its physiological properties this new species is particularly similar to the recently described species Rhodobacter adriaticus, but it shows enough differences compared with $\boldsymbol{R}$. adriaticus and the other Rhodobacter species to be recognized as a separate species. In honor of Hans Veldkamp, a Dutch microbiologist, the name Rhodobacter veldkampii sp. nov. is proposed.
\end{abstract}

During attempts to isolate freshwater strains of the phototrophic purple nonsulfur bacterium Rhodobacter sulfidophilus, Hansen (Ph.D. thesis, University of Groningen, Haren, The Netherlands, 1974) obtained two strains (strains $51^{\mathrm{T}}$ [T = type strain] and 55) of a bacterium which tolerated rather high concentrations of sulfide $(5 \mathrm{mM})$ and grew with sulfide as a photosynthetic electron donor under photoautotrophic growth conditions, but formed (unlike $R$. sulfidophilus) elemental sulfur during oxidation of sulfide. A detailed description of strain $51^{\mathrm{T}}$ was given by Hansen et al. (2), and the characteristic features of this organism were compared by these authors with those of other phototrophic bacteria (in particular, Rhodobacter capsulatus and Ectothiorhodospira shaposhnikovii). Both strains of Hansen were included in a study of deoxyribonucleic acid-deoxyribonucleic acid hybridization of 21 strains belonging to different Rhodobacter species (1), with the result that strains $51^{\mathrm{T}}$ and 55 showed less than $30 \%$ homology to strains of $R$. capsulatus, Rhodobacter sphaeroides, and $R$. sulfidophilus, but $81 \%$ homology to each other. Quite recently, a new species of purple nonsulfur bacteria was described (6), which was assigned to the genus Rhodobacter as Rhodobacter adriaticus after a proposed rearrangement of the phototrophic purple nonsulfur bacteria by Imhoff et al. (4). In many properties strains $51^{\mathrm{T}}$ and 55 resemble $R$. adriaticus (Table 1 ); however, unlike $R$. adriaticus, strains $51^{\mathrm{T}}$ and 55 utilize butyrate and do not utilize glycerol and ethanol, and they can also be distinguished from $R$. adriaticus by their ability to assimilate nitrate, their ability to form chains of cells, their lack of slime production, their vitamin requirement, and their sensitivity to oxygen. $R$. adriaticus has a distinct requirement for sodium chloride and is a true marine bacterium, whereas the new species described below is a typical freshwater bacterium and is inhibited by $\mathrm{NaCl}(6)$. The lipid composition of the new species is different from that of $R$. adriaticus, among others, containing different amino lipids (Imhoff, unpublished data). Large proportions of a sulfoglycolipid (probably sulfoquinovosyl diglyceride) are present in $R$. adriaticus but lacking in the new species. A summary of the distinguishing features of the Rhodobacter species is given in Table 1. In honor of Hans Veldkamp the name Rhodobacter veldkampii is proposed for the new species. In the laboratory of Veldkamp the first phototrophic purple

\footnotetext{
* Corresponding author.
}

nonsulfur bacterium was isolated, which oxidized sulfide during photoautotrophic growth to sulfate by using it as an electron donor for photosynthesis (3). The following description is based entirely on previously published data $(1,2,6$; Hansen, Ph.D. thesis).

Description of Rhodobacter veldkampii sp. nov. Rhodobacter veldkampii (veld. kamp' i. i. M. L. gen. noun veldkampii of Veldkamp; named for Hans Veldkamp, a Dutch microbiologist) cells are short, rodshaped to ovoid, and 0.6 to $0.8 \mu \mathrm{m}$ wide by 1.0 to $1.3 \mu \mathrm{m}$ long, show a pronounced tendency to form chains of cells, do not produce slime, and are nonmotile. Gram negative. Internal photosynthetic membranes are present as vesicles. The color of cell suspensions after anaerobic growth in the light is yellowish brown; small amounts of oxygen cause a color change from brown to red. Absorption spectra of cells grown anaerobically in the light have maxima at $373,448,477,510,589,803$, and $855 \mathrm{~nm}$, indicating the presence of bacteriochlorophyll $a$ and carotenoids of the spheroidene series.

Photoautotrophic growth with sulfide as an electron donor and photoheterotrophic growth with a variety of organic carbon compounds as carbon sources and electron donors are possible under anaerobic conditions in the light. Molecular hydrogen cannot be used as an electron donor. Growth is also possible aerobically in the dark. The carbon sources utilized include acetate, propionate, butyrate, valerate, caproate, caprylate, pelargonate, pyruvate, lactate, malate, succinate, fumarate, glucose, alanine, cysteine, yeast extract, and Casamino Acids; slow growth is possible with glutamate and aspartate. Not utilized are formate, methanol, ethanol, propanol, citrate, tartrate, glycerol, sorbitol, mannitol, fructose, and benzoate. Ammonia, dinitrogen, and nitrate are used as nitrogen sources. Growth depends on the presence of reduced sulfur compounds, such as cysteine, cystine, and sulfide; however, sulfite, methionine, and sulfate are not assimilated.

During phototrophic growth with sulfide as the electron donor, sulfide is oxidized to elemental sulfur, which is only slowly oxidized further to sulfate after sulfide depletion in batch cultures; in sulfide-limited chemostat cultures sulfate is the major oxidation product.

Biotin, thiamine, and $p$-aminobenzoic acid are required as growth factors; $0.01 \%$ yeast extract can replace this requirement. Optimal growth temperature, 30 to $35^{\circ} \mathrm{C}$; optimum $\mathrm{pH}$, 7.5. $\mathrm{NaCl}$ is not required for optimal growth, and is inhibi- 
TABLE 1. Diagnostic features of the species of the genus Rhodobacter ${ }^{a}$

\begin{tabular}{|c|c|c|c|c|c|}
\hline Characteristic & R. capsulatus & R. sphaeroides & R. sulfidophilus & R. adriaticus & R. veldkampii \\
\hline Cell width $(\mu \mathrm{m})$ & $0.5-1.2$ & $0.7-4.0$ & $0.6-0.9$ & $0.5-0.8$ & $0.6-0.8$ \\
\hline $\begin{array}{l}\text { Guanine-plus-cytosine } \\
\text { content deoxyribonucleic } \\
\text { acid (mol \%) }\end{array}$ & $65.3-66.8$ & $68.4-69.9$ & $67-71$ & 66.7 & $64.4-67.5$ \\
\hline Slime production & $+1-$ & + & $+1-$ & + & - \\
\hline Motility & + & + & + & - & - \\
\hline $\mathrm{NaCl}$ requirement & - & - & + & + & - \\
\hline Sulfate assimilated & + & + & + & - & - \\
\hline Nitrate assimilated & $+1-$ & $+1-$ & - & - & + \\
\hline $\begin{array}{l}\text { Photoautotrophic growth } \\
\text { with } \mathrm{H}_{2}\end{array}$ & ++ & Slow & ++ & - & - \\
\hline $\begin{array}{l}\text { Oxidation products of } \\
\text { sulfide }\end{array}$ & $S^{\circ}$ & $\mathrm{S}^{\circ}$ & Sulfate & $S^{\circ}$, sulfate & $\mathrm{S}^{\circ}$, sulfate \\
\hline Vitamins required $^{b}$ & $t(b, n)$ & $\mathrm{b}, \mathrm{t}, \mathrm{n}$ & $\mathrm{b}, \mathrm{t}, \mathrm{n}, \mathrm{p}-\mathrm{ABA}$ & $\mathrm{b}, \mathrm{t}$ & $b, t, p-A B A$ \\
\hline Sulfolipid present & - & + & + & + & - \\
\hline Phosphatidylcholine present & + & + & - & - & - \\
\hline
\end{tabular}

"Data from references 2,3, and 5 through 10 and from studies by Hansen (Ph.D. thesis) and Imhoff (unpublished data).

${ }^{b} \mathrm{t}$, Thiamine; b, biotin; $\mathrm{n}$, niacin; p-ABA, $p$-aminobenzoic acid. Parentheses indicate requirement by some strains only.

tory at concentrations above $2 \%$. Poly- $\beta$-hydroxybutyrate is a storage product. The guanine-plus-cytosine content of the deoxyribonucleic acid is 64.4 to $67.5 \mathrm{~mol} \%$ (thermal denaturation method).

The type strain is strain 51 (Hansen), which has been deposited with the American Type Culture Collection as ATCC 35703

\section{LITERATURE CITED}

1. DeBont, J. A. M., A. Scholten, and T. A. Hansen. 1981. DNA-DNA hybridization of Rhodopseudomonas capsulata, Rhodopseudomonas sphaeroides, and Rhodopseudomonas sulfidophila strains. Arch. Microbiol. 128:271-274.

2. Hansen, T. A., A. B. J. Sepers, and H. van Gemerden. 1975. A new purple bacterium that oxidizes sulfide to elemental sulfur and sulfate. Plant Soil 43:17-27.

3. Hansen, T. A., and H. Veldkamp. 1973. Rhodopseudomonas sulfidophila, nov. spec., a new species of the purple nonsulfur bacteria. Arch. Mikrobiol. 92:45-58.

4. Imhoff, J. F., H. G. Trüper, and N. Pfennig. 1984. Rearrange- ment of the species and genera of the phototrophic "purple nonsulfur bacteria." Int. J. Syst. Bacteriol. 34:340-343.

5. Klemme, J.-H. 1979. Occurrence of assimilatory nitrate reduction in phototrophic bacteria of the genera Rhodospirillum and Rhodopseudomonas. Microbiologica 2:415-420.

6. Neutzling, O., J. F. Imhoff, and H. G. Trüper. 1984. Rhodopseudomonas adriatica sp. nov., a new species of the Rhodospirillaceae, dependent on reduced sulfur compounds. Arch. Microbiol. 137:256-261.

7. Pellerin, N. B., and H. Gest. 1983. Diagnostic features of the photosynthetic bacterium Rhodopseudomonas sphaeroides. Curr. Microbiol. 9:339-344.

8. Pfennig, N., and H. G. Trüper. 1974. The phototrophic bacteria, p. 24-64. In R. E. Buchanan and N. E. Gibbons (ed.), Bergey's manual of determinative bacteriology, 8th ed. The Williams \& Wilkins Co., Baltimore.

9. Trüper, H. G., and U. Fischer. 1982. Anaerobic oxidation of sulphur compounds as electron donors for bacterial photosynthesis. Philos. Trans. R. Soc. London Ser. B 298:529-542.

10. Weaver, P. F., J. D. Wall, and H. Gest. 1975. Characterization of Rhodopseudomonas capsulata. Arch. Microbiol. 105: 207-216. 